\title{
Developing Social Capital In 'Learning Borderlands': Has the Federal Government's budget delivered for low-paid Australian workers?
}

\author{
MAREE KEATING
}

\begin{abstract}
The 2011 Australian federal budget confirmed generous funding for language, literacy and numeracy programs as well as skills recognition and training for older workers as part of a strategy to upgrade workforce skills. In considering possible responses to the announcement, many Australian adult education theorists and practitioners weighed up the contexts in which such programs could build the resources and increase the options of vulnerable workers. One such group of workers, retrenched factory workers, have benefitted from participation in union-run, integrated post-retrenchment programs, which have incorporated access to language, literacy and numeracy as well as vocational education and training programs. Such programs can build on the existing social capital amongst close-knit groups of workers as they develop the confidence to transform their work identities.

This article draws on results from a study with a group of retrenched textile workers who accessed broad-based post-retrenchment support and subsequently participated in a high number of vocational education and training (VET) courses before finding ongoing employment. The study suggests that VET participation plays a limited role in broadening the employment opportunities for retrenched factory workers who move into low-paid occupations. Whilst VET participation alongside other factors supported entry into some occupations, it played no role in supporting most workers in their transitions into non-manufacturing jobs.
\end{abstract}

\section{Introduction}

The announcement of the federal Australian budget in June 2011 affirmed government commitment to 'language and literacy' and 'skill development' for vulnerable and marginal workers through the allocation of \$30 million for the 'More Help for Mature Age Workers initiative'. In addition to this VET funding, a further $\$ 143$ million was promised for 30,000 additional commencements in the Language, Literacy and Numeracy Program (LLNP) alongside a further $\$ 20$ million to continue the Workplace English Language and Literacy program (WELL). These programs are linked through policy rhetoric to the larger strategy of upgrading skills for the Australian workforce, 'to boost productivity, increase 
workforce participation and ensure [the government's] social compact with Australians to deliver the dignity of work' (Evans 2011).

Whilst funding for literacy and vocational education initiatives are to be applauded, questions have been raised regarding their capacity to reduce vulnerability and social exclusion amongst Australian low-paid workers. Previously identified problems impeding the success of such programs include barriers to access (Cully et al 2000, Watson 2003, Gringart et al 2005), conceptions of skill and pedagogical approaches to skill development (Buchanan et al 2001, Karmel and Woods 2004), poor articulation of the literacy skills involved in work practices (Billett and Somerville 2004) and lack of engagement with social partnership models (Harris et al 2009, Young 2002, Balatti et al 2009).

The positioning of vocational education programs within current international discourses surrounding workforce skills warrants critical analysis, as does the design of such programs. This is especially so as governments have sought to engage low-paid workers in VET with the promise that it can reduce the levels of worker vulnerability which have accompanied global restructuring processes (Lakes and Carter 2004, Billet et al 2006, Fenwick and Hall 2006, Farrell and Fenwick 2007). Martin and Knudsen (2010) point out that as globalised manufacturing processes force more manufacturing workers in OECD countries into the lower end of the services sector, national VET systems and labour market approaches produce particular worker choices and industry skill patterns. VET is often positioned as a policy cornerstone in the management of social changes taking place in developed nations. The increased marginalisation of those who occupy unskilled jobs has negative implications for retrenched manufacturing workers as a group and, as some suggest, creates disharmony between social classes (Martin and Knudsen 2010:347).

In Australia, VET programs have been promoted to employers and workers alike, as a means of generating both increased workforce skill and individual opportunity in low-paid industries and occupations (Department of Education, Employment and Workplace Relations [DEEWR] 2008). The funding of such programs is invariably announced with emphasis on government commitment to both national business productivity and social inclusion, although the problems inherent in this dual focus have been enumerated by VET researchers over the past decade (Equity Research Centre 2006).

Most recently, Pocock et al (2011) have shown that VET participation does not necessarily lead to increased opportunities for Australian low-paid workers. Despite the fact that low-paid workers comprise a sizeable segment of the population, consisting predominantly of women and young people, and are concentrated in particular industries, Pocock (2009) points out that 
existing research does not explore what 'enables or inhibits' their work transitions, or how VET can facilitate their movement out of low paid work. According to the National Centre for Vocational Education Research (NCVER), the increased national participation which is taking place in VET is not necessarily resulting in increased employment outcomes, with a recent report stating that:

The proportion of graduates who improved their employment circumstances after training has decreased by 4.4 percentage points from 2006 to 2010 and by 3.8 percentage points for students from most disadvantaged backgrounds from 2007 to 2010 (Hargreaves 2011: 1).

Very little has been written about the experiences of retrenched Australian manufacturing workers who do participate in VET as they make the transition into low-paid service sector jobs. Given the policy rhetoric surrounding government funding commitment to VET and the very real impact of global restructuring on these workers in Australia and other OECD countries, it is important to develop an understanding of the conditions under which VET might contribute to their employment opportunities.

There are two lines of argument made in this article. Firstly, the article outlines the ways in which the social capital belonging to a group of recently retrenched textile workers was utilised to maintain resilience and increase VET participation. Participants in a union-based postretrenchment program were able to build new strategies towards occupational transitions alongside their participation in VET courses. The broad support program utilised adult literacy principles involving partnerships, policy advocacy and pedagogical best practice (Balatti et al 2009) to maintain existing social capital amongst this vulnerable group of workers. Analysis of the program results offers some insight into the importance of 'learning borderlands' in increasing workers' participation in VET courses and in making transitions into new kinds of work. I suggest that 'learning borderlands' created through programs like these allow workers to maximise existing social capital as they undertake training, apply for new jobs and navigate unfamiliar processes in the labour market.

Secondly, the article draws from qualitative research conducted with the retrenched textile workers from the above program, focusing on a group who successfully entered and maintained ongoing employment afterwards. Whilst significant numbers of participants in the program undertook VET courses in 2005 and 2006, this research found that VET qualifications were rarely associated with increased job opportunities amongst this group. 
Participation in VET was considered by many to have had strategic importance in maintaining post-retrenchment optimism. However, for those without the requisite dispositions or social capital, VET qualifications did not increase their options or their chances of entering and maintaining jobs outside of manufacturing.

The analysis of worker experiences suggests that, within this group post retrenchment programs lead to increased VET participation and optimism. However, such VET participation confirms the existing match between worker attributes and the occupations they aspire to, without supporting the critical learning involved in entering or maintaining new employment. Further, VET is often of low relevance in the career trajectories of retrenched manufacturing workers, either because the match between their worker attributes and the occupations they enter is already strong enough to secure them a job without training, or because regardless of the training, the match is too weak to result in success. In discussing these factors, the conceptual framework of the 'habitus', the 'disposition' and 'capital' provided by Bourdieu (1986), proves useful. I conclude that under current conditions, most retrenched manufacturing workers in Australia will not benefit from increased government funding to VET unless they are accompanied by opportunities for workers to develop social capital for new industries and occupations. Spaces within which workers can learn, socialise and exchange with mentors and fellow workers are vital for the development of valuable social capital. Such spaces, or 'learning borderlands' within occupations, may not only allow able and qualified workers to access jobs, but also to broaden their ongoing employment options and skill development.

\section{The role of learning borderlands in generating social capital}

In considering the value of funding for VET and language, literacy and numeracy (LLN) programs for retrenched manufacturing workers, we must first identify how movement into and then progress within new occupations takes place for this group. Whilst VET is promoted to retrenched workers, the specific benefits of a qualification arise from the ability of a worker to utilise them, which is in part determined by that worker's networks and in part by the relative value of the qualification and the worker in the eyes of the employer.

We know that 'embodied learning' for each occupation is distinct, producing different ways of thinking and learning across worker groups (Billett and Somerville 2004). We also know that general skills are of most use in career transitions amongst workers at the lower-paid end of the Australian economy (Karmel et al 2008). VET qualifications promoted to 
retrenched manufacturing workers usually provide licences, certificates and occupational health and safety requirements for entry-level employment in retail, hospitality, construction, driving, administration, cleaning, security and caring jobs. Experienced, retrenched manufacturing workers often have a range of general skills. Despite the combination of experience, new work aspirations and VET qualifications, many find that they are unable to make the transitions into desirable jobs. Others may be able to do so regardless of their VET qualification. This phenomenon poses a conundrum for VET policy makers who argue that VET participation increases opportunities for retrenched manufacturing workers. The 'dispositions' of workers and their accumulated 'social capital' often prove to be more significant in overcoming labour market disadvantages.

One of the challenges that low-paid Australian workers face is the struggle to access the necessary employment information, advice and support to maintain their often precarious employment (Pocock 2009). Theorists such as Granovetter (1973) and Coleman (1988) suggest that social networks, ties and bonds are crucial for workers undergoing a process of transformation, because relationships generate various kinds of 'social capital' which can be drawn upon to either enter into or maintain power and influence in new fields. In their current form, Australian VET courses are neither generic enough to assist participants to build networks and strategies for maintaining employment, nor are they usually specific enough to give participants work experience with potential employers. Within this context, in considering how VET participation may benefit retrenched manufacturing workers, it is important to identify the ways in which these workers prepare for, enter and maintain new jobs and occupations, and the way 'social capital' is utilised in those processes.

Bourdieu (1986:241) defines social capital as 'the aggregate of the actual or potential resources which are linked to possession of a durable network of more or less institutionalised relationships of mutual acquaintance and recognition'. His concept of social capital is particularly useful when considered alongside those of 'individual disposition', the 'habitus' and the 'field', as it assists adult education theorists to think about learning within the fluid and multi-layered process of social and individual change. Bourdieu's concepts have been used by several adult education theorists in discussing the interactions between individual life trajectories, occupational constructions and models of learning (Sawchuck 2003, Warren and Webb 2007, Wojecki 2007). They have not previously been applied to consider the benefits of VET in the transitions of manufacturing workers in developed countries.

According to Bourdieu (1980), one's individual 'disposition' arises out of the accumulation of life experience and education, social position, networks, and identity background which gives one person a strategic 
advantage in playing the 'game' relevant to that 'field'. Importantly, as has been noted by others, 'dispositions' of workers are inherently open to change, dependent upon the fields in which individuals engage and also the life experiences one acquires (Warren and Webb 2007, Huppatz 2010). Major life disruptions such as retrenchment can provide workers with opportunities to acquire 'dispositions' for new kinds of work arising under changed social conditions. Access to relevant social capital will largely determine their success in this process, and ultimately, as workers in a new field.

Using Bourdieu's conceptual framework, workers' ability to gain a strategic advantage within a new occupational 'habitus' or 'system of dispositions' is partly contingent on the material, social and cultural capital they can draw upon. Adult education theorists have elsewhere utilised the notion of a 'vocational habitus' to analyse the interplay between individuals, learning processes and entry into particular fields of work (see for example Colley et al 2003). Some workers will bring a dispositional advantage with them into the new occupational 'game', because of identity factors and networks of influence and support. An individual's 'social capital' for work is generated through meaningful participation in networks of durable relationships, which provide a sense of familiarity with the particular 'field' of work. Short-term training courses, on their own, can rarely foster the sorts of durable networks that support and sustain major life transitions. Cuban (2009:5) has referred to spaces around formally funded programs as 'learning borderlands'. Within the changing work habitus, peripheral culture, marked by resistance and 'borderland discourses' thrive amongst marginalised workers (Billett and Somerville 2004, O'Connor 2004). For retrenched textile workers moving into less organised and more peripheral work within developed economies (Lambert and Webster 2010), the term 'borderland' is particularly apt. It describes the states that these retrenched workers enter as they disinvest from aspects of their previous work dispositions and become workers in a field marked by different rules and requiring different kinds of 'capital'. For the purposes of this article, Bourdieu's broad conception of 'social capital' sufficiently suggests the full range of resources and benefits that may accrue to an individual through their network associations.

\section{Background to the study}

In the 20-year period from 1985 to 2005, full-time employment in the Australian textile, clothing and footwear (TCF) industries fell dramatically from 104,800 to 42,800 workers (Weller 2007). The impact of job losses on textile workers and their communities has been documented at different times during that period, and the literature consistently demonstrates that 
such workers are highly vulnerable to long term unemployment, increased stress and reduced well-being (Webber and Weller 2001, Lipsig-Mumme and Neilsen 2003). The Textile Clothing and Footwear Union of Australia (TCFUA) calculated around 2,000 TCF workers had lost their jobs due to closures and downsizing operations in metropolitan and rural centres in Victoria between 2004 and 2006 (TCFUA 2006).

In response to the findings of the Productivity Commission (2003), in 2005 the Australian federal government announced the introduction of the TCF Structural Adjustment Package (SAP). The package was to make $\$ 50$ million available over ten years to ameliorate the negative impacts of industry restructuring on workers and their communities (DEEWR 2005). In principle, the SAP made retrenched TCF workers eligible for immediate job search support through a government job agency. It also provided access to free vocational education courses as long as these were determined by their case managers to be relevant to their job seeking process. The federal government's training support package sat alongside a similar Victorian state government re-training program, which provided retrenched textile workers with access to VET courses, to be utilised up to six months after retrenchment (Skill Up program). The TCFUA played a considerable role in making both packages accessible to retrenched workers between 20052008, whilst advocating to both state and federal governments for more effective program design and implementation (TCFUA 2006).

The case for an integrated (i.e. 'built in') literacy model of training and support for retrenched TCF workers was made during that time. This work drew upon previous longitudinal studies which had been conducted with this particular retrenched worker group (Webber and Weller 2001, Lipsig Mumme 2003). These studies noted the confluence of factors working against retrenched workers in re-entering the workforce, and recognised the broad social benefits to workers of holistic support and integrated learning programs.

In 2005 the TCFUA piloted an integrated literacy model for delivery of support and training to retrenched TCF workers. The pilot was funded under a grant from the Australian National Training Authority (ANTA) and utilised the Australian Council for Adult Literacy (ACAL) definition of literacy which, aside from integrating listening, speaking, reading, writing, critical thinking and numeracy, also included 'the cultural knowledge that enables a speaker, writer or reader to recognise and use language appropriate to different social situations' (ACAL 1998). Within the integrated literacy model, the 'cultural knowledge' and the language of work practices within the new work 'habitus' were central. This strategy emphasised the importance of 'developing networks, discourses and opportunities for exchange amongst retrenched worker communities, rather than focusing narrowly on the skills for surviving and competing as casual 
labour in individualised work environments' (TCFUA 2005:3). It was considered that the existing 'social capital' amongst groups of retrenched workers might assist them to develop their resilience and job seeking strategies and maintain optimism as they encountered and engaged with the new field of work. Ultimately, it was anticipated that participation in the post-retrenchment support program would increase VET uptake and thereby improve employment outcomes amongst the retrenched group.

The 'social capital paradigm' laid out by Balatti et al (2009) enumerates a range of benefits in incorporating a 'social capital' focus into vocational training. They conclude that a national and collaborative adult literacy and numeracy policy that embraces social capital is an appropriate response in a political and social climate in which social exclusion is considered unacceptable' (Balatti et al 2009:9). The pedagogical strategies central to their 'social capital teaching paradigm' in literacy and numeracy education encourage students to build bonding, bridging and linking ties within and outside of the learning environment, focus on strong teacher student relationships, build peer learning and collaborative teaching partnerships and embed literacy and numeracy learning into other activities.

The TCFUA model of post-retrenchment support incorporated advice and support to access free VET courses as part of its broad program of support. In this way, a 'learning borderland' was consciously constructed, in which recently retrenched workers could engage in broad processes of learning to accompany their engagement with more narrowly-focused VET courses. In this borderland, retrenched workers could critically engage with change processes alongside a trusted group of familiars.

\section{The Feltex retrenchment}

Whilst many retrenched TCF workers underwent VET courses through the TCFUA post-retrenchment programs in 2005 and 2006, it remained unclear whether or how VET participation had assisted them to enter, maintain or progress within jobs in the changing field of low-paid work. During that period the union conducted a number of telephone surveys to determine retrenched TCF workers' participation in VET and employment outcomes six months after retrenchment (TCFUA 2006), and it is clear that union programs played a significant role in increasing the overall uptake of VET amongst this group.

However, there has been little analysis of how VET participation or other post-retrenchment support interacted with processes of personal change, learning and work transitions within the lives of retrenched TCF workers. Questions remained as to what role VET qualifications played in advancing their employment opportunities, reducing their vulnerability to unemployment or supporting their work transformations. 
Of the many companies that closed their doors or downsized during that period, one particularly large retrenchment involved 165 textile workers losing their machine operator jobs at Feltex Carpets in the western suburbs of Melbourne in October, 2005. A large proportion of these workers underwent vocational education and training as part of their participation in a union-run post retrenchment support project.

One factor that made this retrenchment particularly interesting to document was that the company agreed to fund a TCFUA-run, postretrenchment project which would link the 165 retrenched workers to vocational education courses, provide advocacy support around job search and funding access, and run tailored literacy, computer and Certificate of General Education for Adults (CGEA) courses over a 12 month period (October 2005-October 2006). This program was particularly well utilised by retrenched Feltex workers over the period, as they had received their full retrenchment entitlements, resulting from staunch industrial bargaining processes and healthy company liquidity. Retrenched workers were therefore able to come together as a group in numerous ways over 12 months, with many receiving group and individual support and advice, taking part in arts, general education and social events and accessing multiple, free VET courses of their choice.

The following part of this article presents aspects of the research conducted with members of the retrenched Feltex group after the support program finished. Research activities took place between January 2007 and late 2008. Findings from this research confirm the benefits to workers in participating in integrated post-retrenchment support, but it became clear that VET qualifications, whilst sometimes facilitating retrenched manufacturing workers' entry into particular occupations, did not tend to increase work opportunities.

\section{Research methodology}

As a TCFUA researcher who had previously been involved in the implementation of the post-retrenchment support program throughout the period from October 2005 until October 2006, I had the opportunity to observe the retrenched workers over a prolonged period. The TCFUA then agreed to make the project material available for the purposes of finding research participants after the program finished. All project participants had signed an agreement authorising the TCFUA to do so.

At the end of the 12 month project with retrenched Feltex workers, the TCFUA recorded that 64 out of 123 re-contacted retrenched workers were re-employed, $62 \%$ of whom ( 40 workers) were working in non-factory environments outside the manufacturing sector (Keating 2010). A further 15 of those contacted were actively looking for work. The remaining 44 workers were either retired (27), studying (five) or on Workcover (12). 
In January 2007, using TCFUA project data, I conducted a telephone survey with 43 of the workers who were either working or looking for work at the end of the project. Twenty men and 23 women took part. I introduced myself saying that I was not calling on behalf of the TCFUA but as an independent researcher. After I explained the nature of the research, all consented to take part in the 30 minute phone survey and agreed to be contacted again in the future as required.

The telephone survey was designed to ascertain the work and training experiences amongst those in the group who had successfully re-entered employment in the 12 months after retrenchment. I asked both qualitative and quantitative questions about their job-seeking experiences, the amount of training undertaken, the perceived usefulness of training, the number and length of jobs held, sources of support and views on new workplaces and work conditions in the first 15 months after retrenchment. Discussions were transcribed using a computer and a hands-free speaker-phone. The results from this survey helped to shape questions for more in-depth face-to-face interviews the following year.

In the middle of 2008, I approached the previously surveyed retrenched workers by phone, asking if I could meet them for a one-hour to 90-minute face-to-face interview. Seventeen interviews resulted with retrenched workers (eight men and nine women) of mixed ages (27 to 62 years), all of whom had retained employment with one employer for at least 18 months since retrenchment from Feltex. The interviews would provide more detailed narrative data about retrenched workers' experiences and perceptions of change over the three years since retrenchment, in order to shed light on what learning had been involved in the process of change and what had supported that learning.

Data comprised three areas: the changing role of work in participants' lives, their changing sense of belonging, and their changing views on knowledge and learning. Interviewees signed consent forms prior to interviews saying that they understood what the project was about, that they did not have to answer questions and indicating they were happy to have their words quoted and their names published. Two of the women had recently left the jobs they had held for 18 months, but were looking for work again. The rest were all still working in jobs they believed were ongoing and which they had held for 18 months.

According to Bourdieu (1990:42), 'a full and complete sociology should clearly include a history of the structures that are the product at a given moment of the whole historical process'. Changes are taking place in the individual lives of one group of Australian workers and this research suggests that a relationship exists between this set of changes and a new system of dispositions, or 'habitus' at the low-paid end of the Australian 
workforce. The learning requirements which accompany worker transformations in low-paid jobs therefore have a much broader nature than simply acquiring the technical skills of driving, cleaning or serving customers. The social capital workers were able to acquire as they entered and then navigated the new field of low-paid work would heavily influence their opportunities and their resilience in that field. In most cases, participation in VET would not.

\section{Findings from the research}

Prior to this research, I had assumed that engagement with VET would contribute to improved employment outcomes for the Feltex workers. Employment opportunities at the lower end of the economy are increasingly mediated by combined recruitment and training services. The current training-for-work agenda emerges out of highly contested shifts in the field of education, particularly in relation to its role in producing skilled workers for industry and simultaneously increasing employment access for those disadvantaged in the labour market. Findings from this research suggest, however, that despite new policy alignments between industry and education, highly motivated, determined and skilful individuals exiting the manufacturing sector are often unable to use VET as a resource in their transformations as workers.

The initial telephone survey of 43 Feltex workers provided some information about the circumstances under which VET qualifications were useful. Fourteen of the men and 19 of the women surveyed had participated in VET courses during the post-retrenchment program period. Whilst half of the men who undertook training completed one course, the other half had completed multiple courses. The overwhelming majority of the courses were in transport-related certificates and licences.

Whilst seven women had completed one course, 12 had completed multiple courses in the 12-month period. In 2006 there were 20 enrolments in general education courses amongst the 23 women surveyed. These included LLN courses, the GGEA and computer skills courses. Importantly, most of the women who had undertaken one of these had later undertaken other vocational courses. Comments from survey respondents indicated that general education courses boosted their self-confidence, addressed gaps in their basic education, and provided an opportunity to maintain social contact and support with others. Apart from the general education courses, 18 additional vocational courses were ultimately undertaken by women. These were in aged care, food handling, librarianship, medical secretarial training, retail, security, asset maintenance (cleaning), hospitality, and forklift driving.

Fourteen workers had directly utilised VET certificates and licences to enter casual jobs. Eleven of these were men who reported that the training 
had allowed them entry into forklift and truck driving, taxi driving and security jobs. By contrast, only three women found that VET qualifications assisted them in finding a job. They were all employed on part-time contracts in the aged care industry.

The remaining 29 survey respondents reported that the VET training they undertook in 2006 did not play any role in helping them acquire new jobs. Only three men reported indirect benefits of VET participation, commenting that 'the training got me back into the swing of things', 'it kept the options open' and 'it gave me some new skills'. By contrast, 'indirect benefits' of training were commonly reported by women. One woman reported, for example, that getting her driver's licence directly impacted on her life in many positive ways, although finding a job was not one of them. Another reported that learning about using computers had directly changed her life as she now used them all the time for practical daily activities such as paying bills and emailing people. Ten other women reported that although they had not found work as a result of VET participation, their participation in the post-retrenchment program and training increased their general confidence in life, gave them an experience of learning which was valuable in itself, opened up a new social world, or provided them with 'future options' to consider.

This response, revealing that most participants did not directly use VET qualifications to enter new jobs, was not necessarily surprising. A survey of student outcomes by Karmel and others (2008) found that the relevance of Australian VET qualifications to job outcomes in the relevant industry or job are highly nuanced and that 'soft skills' were often the elements of VET courses which added value to graduate outcomes in occupations other than those for which they trained.

It remained unclear in my study, however, how VET participation had interacted together with other factors for those who found and maintained employment in new jobs and occupations. In order to investigate this, in-depth interviews were examined to identify the contexts in which VET was of benefit to retrenched workers.

It is not possible here to provide an in-depth discussion of the rich worker narratives emerging through the 17 interviews with those who maintained employment. A number of themes did, however, emerge, which shed light on the process of transformation itself. Participants talked about the ways in which their worker identities and their sense of belonging to various communities had changed in the years since retrenchment. For most, customer focus, entrepreneurship and dispersed social networks, as well as acceptance of change and openness to learning, had become central to their approach to work and also to life more generally. In this sense, 'dispositions' had changed considerably amongst all of the respondents. In 
all cases there was a level of ambivalence about this change, although for three of the workers in particular, life was felt to be significantly better as a result. Each of these three workers had found stable, ongoing work for which they were well suited and qualified. One was a long distance truck driver, one an aged care worker in two different organisations and one a team leader in a manufacturing setting. The two men had trade qualifications and were born in Australia. The woman had completed 12 years of education in an English-speaking environment.

For all of those interviewed, success in entering and then maintaining employment in new jobs depended first upon their capacity to network with trusted friends and colleagues, and then later, they were dependent upon sourcing advice and information through other workers, employers, customers and clients in their industry. The two women who had chosen to enter the aged care industry found that they were easily able to secure and maintain ongoing part-time jobs, firstly because their VET courses offered work placements, and then because they quickly developed new networks of other workers and employers who could refer them to potential workplaces.

The women interviewed were all from non English-speaking backgrounds and had participated in general education and English language courses. They had all relied on vocational training courses to open job opportunities. Women with higher educational qualifications and previous senior work experience in their countries of origin had been particularly keen to undertake VET qualifications, as well as those with gaps in their basic education and no experience outside manufacturing. All had initially believed VET participation would increase their employment opportunities.

However, whilst two of the women used their qualifications to enter jobs in aged care, three other women had hoped to use VET qualifications to move into administrative, office-based or customer service-based employment, for which they had previously qualified and in which they had experience. None had been unable to forge the necessary social connections to access or maintain employment in their desired jobs. These three women, who had participated in librarianship, administration training and hospitality courses, had eventually all returned to unqualified and insecure jobs in manufacturing, warehousing and home care. These jobs were not reliant on VET qualifications but rather, their previous life and work histories. Another woman who had undertaken numerous certificates with the hope of entering into work in the security or hospitality industries, had found unqualified cleaning work, having been unable to find adequate mentoring support to enter jobs for which she had qualified. One woman had used her previous experience in industry and her recently acquired diploma in retail to enter a shop management job, but had then been unable to secure another retail job after she lost that position. They each talked 
about the lack of networks through which they might draw the relevant information, support and advice to enter a new occupation.

The men interviewed had generally relied less than women on 'social capital' they might build from training participation. The two Australianborn men with team leader experience (mentioned above), had undertaken VET courses, but then used their existing social networks to find secure jobs in manufacturing and long distance truck driving. Another young Australian-born man undertook a VET course to acquire a Red Card for the construction industry but secured an ongoing job in steel manufacturing without undergoing the apprenticeship his new employer eagerly offered him. For two of the men from non English-speaking backgrounds, training had performed a perfunctory role in providing them with driving licences, but they had been able to enter and maintain truck driving and taxi driving jobs through the support and advice of their brothers, who were established in these industries. Since starting their new jobs, neither had been able to source advice through new networks, as they worked in isolation. Two older, non English-speaking background men did not participate in VET courses, but found ongoing work in manufacturing and warehousing jobs on the basis of their work histories.

\section{Discussion and conclusions}

Australia has long been regarded as having one of the highest rates of casualisation in the workforce and the disparity between the highest and lowest-paid workers has continued to grow (Hanrahan 1999). The Australian Government recognises that VET has a critical role to play in addressing the disadvantages faced by retrenched TCF workers (Productivity Commission 2003). It is therefore important to consider how VET is perceived and experienced by those workers.

Changes in outlook and expectations brought about by work experiences are in themselves learning processes, which affect identity and ideas of class-belonging (Crossan et al 2003, Sawchuck 2003). However, the ways in which learning re-shapes individual lives are neither uniform nor inevitable, but result from the interplay between social and individual factors and often reflect the structures of industries and jobs (Webb and Warren 2009).

Adult education theorists have argued that skilful practices amongst workers emerge out of collectively agreed and reinforced values and social processes that are particular to the group of workers or the workplace (Gerber 2000, Engestrom 2001). For many Australian low-paid workers, work practices are increasingly acquired in the absence of work groups or workplaces. Individual workers draw on the information and advice they can glean through new, loose networks. However, their loose 'belonging' in 
these groups does not tend to create social capital with which they can improve their overall opportunities or conditions within the new field of lowpaid work. Numerous examples of this emerged in the interviews.

Ahmed, the taxi driver in this study, was able to recount the ways in which he had refined his communication skills to access extra tips and job opportunities with customers, although he felt that without the support of other taxi drivers, he could not address issues of safety and threats of violence inherent in his working conditions. Zaim reflected that, whilst he was friendly with other truck-driving contractors, the only information he could access about how to negotiate payments from customers, find legal support and manage his workload came from his brother, an experienced private contractor. Florica, working as a casual night-shift cleaner, was dissatisfied and bored with her job and wanted to work as a security officer. However, like Levy, a qualified receptionist who could only find work as a carer in the home of a private family, she felt could not utilise her recently acquired VET qualifications, experience and skills to find a job she preferred. Both identified lack of mentoring, networks, contacts and advice as real barriers to them in finding more stimulating and secure work in areas for which they were qualified. For these workers, VET qualifications had been of little practical use in reducing their marginal status as casual and isolated workers.

With declining unionism and increasing job fragmentation amongst low-paid workers there is great value in creating learning environments around VET programs in which participants can use their existing social capital to maintain confidence and plan their transitions. Increased VET funding which fails to support such approaches is unlikely to result in significant VET participation amongst retrenched manufacturing workers. It is clear that this group, and in particular women, undertake VET when it is part of a broader, supported process in which confidence and new aspirations are generated.

Despite the policy rhetoric, however, it appears that retrenched workers' job opportunities are rarely broadened through their participation in VET courses. Women's low-paid work options outside of aged care lie predominantly in occupations where high rates of casualisation and fragmented work roles make it difficult for them to forge crucial networks and relationships through which to source information and advice vital to their advancement. Their entry into administrative and office based jobs and their ongoing employment in the retail sector require them to forge networks and contacts as part of their broad learning for work transitions. Men, often able to access initial driving and labouring jobs through their existing networks, can remain unable to broaden their opportunities once they are employed, for similar reasons. 
Although a significant number of VET courses were completed by members of this group, the impact of VET qualifications on the employment outcomes for those who had successfully retained employment in a new occupation was very uneven. Most of these Feltex workers had been able to acquire stable jobs in new occupations as a result of factors other than a VET qualification. Many remained unable to convert VET qualifications into employment outcomes due to factors related to disposition and networks. Worker 'dispositions' (including age, gender, class and language background) needed to be favoured in the occupations to which they aspired. Networks were critical for Feltex workers in entering employment but also in maintaining resilience and employability within new occupations.

Participation in VET can be a valued experience for retrenched factory workers for a range of reasons. Such participation can have a particularly positive impact on women, who are often less likely than their male counterparts to have the confidence or networks to find ongoing jobs in new occupations. Participation in VET may also qualify workers to gain entry-level employment into new occupations. However, under current conditions in low-paid occupations, VET funding does not contribute to improved employment opportunities for retrenched manufacturing workers outside of a limited number of low-paid occupations, such as aged care, where learning borderlands support workers to develop social capital.

Government funding for vocational training currently promises to provide retrenched, vulnerable factory workers with a platform for change, although in the Australian context VET, to be a resource for this group, needs to be accompanied by integrated post-retrenchment support programs and longer-term workforce education and industry development strategies which create the social environments in which vulnerable workers can build networks and learn. This discussion has reinforced findings elsewhere that mature aged workers undergoing high-risk transformations at the most vulnerable end of the 'new work order' can often fail to benefit significantly from the training courses they undergo, despite targeted policy attention to re-skilling (Armstrong-Stassen and Templer 2005, Keating 2010).

Effective learning spaces must be created alongside the LLN, WELL and VET programs announced in the 2011 budget, if they are to reduce low-paid worker vulnerabilities. In the borderlands around working life, VET participants need opportunities to make enduring friendships and connections that can become sources of social capital as they traverse the unknown terrain of their new occupations. Unless this funding is conceptualised as part of a broader social policy project, in which industries develop the social conditions for broader learning, the Feltex study indicates 
that social inequalities between workers in Australia will continue to be further entrenched under new work conditions and training may fail to deliver for Australia's most vulnerable workers.

\section{References}

Australian Council for Adult Literacy (ACAL) (1998) Surveys and Beyond: The case for adult literacy, ACAL, Canberra.

Armstrong-Stassen, I and Templer, A (2005) Adapting Training for Older Employees: The Canadian response to an aging workforce, The Fournal of Management Development, vol 24, no 1, pp 57-67.

Balatti, J, Black, S and Falk, I (2009) A New Social Capital Paradigm for Adult Literacy: Partnerships, policy and pedagogy', National Centre for Vocational Education Research (NCVER), Adelaide.

Billett, S and Somerville, M (2004) Transformations at Work: Identity and learning, Studies in Continuing Education, vol 26, no 2, pp 309-26.

Billet, S, Fenwick, T and Somerville, M, eds, (2006) Work, Subjectivity and Learning, Springer, Dordrecht.

Bourdieu, P (1980) The Logic of Practice, Blackwell, Oxford.

Bourdieu, P (1986) The Forms of Capital, in Richardson, J, ed, Handbook of Theory and Research for the Sociology of Education, Greenwood, New York, pp 241-258.

Bourdieu, P (1990) In Other Words: Essays towards a reflexive sociology, Stanford University Press, Stanford.

Buchanan, J, Schofield, K, Briggs, G, Considine, G, Hager, P, Hawke, G, Kitay, J, Meagher, G, Macintyre, J, Mournier, A and Ryan, S (2001) Beyond Flexibility: Skills and work in the future, Final report of the NSW Board of VETresearch project, The Changing Nature of Work: Vocational education and training to enable individuals and communities to meet the challenges of the changing nature of work, NSW Board of VET, Sydney.

Coleman, J (1988) Social Capital in the Creation of Human Capital, American Fournal of Sociology, vol 94 (Supplement), pp S95-S120.

Colley, H, James, D, Tedder, M and Dement, K (2003) Learning as Becoming in Vocational Education and Training: Class, gender and the role of vocational habitus, Fournal of Vocational Education and Training, vol 55, no 4, pp 471-496.

Crossan, B, Field, J, Gallacher, J and Merrill B (2003), Understanding Participation in Learning for Non-Traditional Adult Learners: Learning careers and the construction of learning identities, British Journal of Sociology of Education vol. 24, no. 1, pp. 55-67.

Cuban, S (2009) Outside Practices: Learning within the borderlands, Literacy and Numeracy Studies, vol 16, no 2 \& Vol 17, no 1, pp 5-18. 
Gully, M, Vandenheuvel, A, Curtain, R and Wooden, M (2000) Participation in and Barriers to Training: The experience of older adults, Australasian Fournal on Ageing, vol 19, no 4, p 8.

Department of Education, Employment and Workplace Relations (DEEWR) (2005) Textile Clothing and Footwear Structural Adjustment Package, Australian Government, Canberra.

Department of Education, Employment and Workplace Relations (DEEWR) (2008) Skilling Australia for the Future: Discussion paper, Australian Government, Canberra.

Evans, C (2011) media release, http://ministers.deewr.gov.au/evans/building-educated-and-skilledworkforce, viewed February 7, 2012.

Engestrom, Y (2001) Expansive Learning at Work: Toward an activity theoretical reconceptualization, Fournal of Education and Work, vol 14, no 1, pp 133-156.

Equity Research Centre (ERG) (2006,) State of Equity Report, ERC, Melbourne.

Farrell, L and Fenwick, L (2007) Educating the Global Workforce, Routledge, London and New York.

Fenwick, T and Hall, R (2006) Skills in the Knowledge Economy: Changing meanings in changing conditions, Fournal of Industrial Relations, vol 48, no 5, pp 571-74.

Gerber, R (2000) Experience, Common Sense and Expertise in Workplace Learning, in Gerber, R and Lankshear, C, eds, Training for a Smart Workforce, Routledge, London and New York.

Granovetter, M (1973) The Strength of Weak Ties, The American Fournal of Sociology, vol 78, no 6, pp 1360-80.

Gringart, E, Helmes, E and Speelman, C (2005) Exploring Attitudes Toward Older Workers Among Australian Employers: An empirical study, Fournal of Aging \& Social Policy, vol 17, no 3, pp 85-103.

Hanrahan, $\mathrm{P}$ (1999) Work as Paid Employment: What is changing and why? An Australian Perspective, paper presented at AVETRA conference, Melbourne 2000, viewed June 30 2008, $<$ http://www.avetra.org.au/abstracts_and_papers_2000/phanrahan full.pdf $>$.

Hargreaves, J (2011) Vocational Training and Social Inclusion, National Centre for Vocational Education Research (NCVER), Adelaide.

Harris, R, Simons, M and Maher, K (2009) New Directions in European Vocational Education and Training Policy and Practice: Lessons for Australia, Gentre for Research in Education, Equity and Work, University of South Australia, Adelaide.

Huppatz, K (2010) Class and Career Choice: Motivations, aspirations, identity and mobility for women in paid caring work, Fournal of Sociology, Vol 46 No 2, pp 115-32. 
Karmel, T and Woods, D (2004) Lifelong Learning and Older Workers, National Centre for Vocational Education Research (NGVER), Adelaide.

Karmel, T, Mlotkowski, P and Awodeyi, T (2008) Is VET Vocational? The relevance of training to the occupations of vocational education and training graduates, National Centre for Vocational Education Research (NGVER), Adelaide.

Keating, M 2(010) Learning from Retrenchment: Local textile workers redefine themselves after global restructuring, $\mathrm{PhD}$ thesis, RMIT University, Melbourne.

Lakes, R and Carter, P, eds, (2004) Globalizing Education for Work: Comparative perspectives on gender and the new economy, Laurence Elhbaum Associates, Mahwah.

Lambert, R and Webster, E (2010) Searching for Security: Case studies of the impact of work restructuring on households in South Korea, South Africa and Australia, Fournal of Industrial Relations, vol 52, no 5, pp $595-611$.

Lipsig-Mumme, C and Neilsen, I (2003) The Long Goodbye: TCF workers, unemployment and tariff deregulation, Report for Department of Innovation, Industry and Regional Development, State Government of Victoria, Melbourne.

Martin C and Knudsen, J (2010) Scenes from a Mall, Regulation $\&$ Governance (2010), no 4, 345-364.

O'Connor P (2004) Workers' Texts, Identities and Learning Possibilities in the Smart Workforce in Gerber, R and Lankshear, C, eds, Training for a Smart Workforce, Routledge, London and New York.

Productivity Commission (2003) Review of TCF Assistance, position paper, Australian Government, Canberra.

Pocock, B (2009) Low-Paid Workers, Changing Patterns of Work and Life, and Participation in Vocational Education and Training: A discussion starter, National Centre for Vocational Education Research (NCVER), Adelaide.

Pocock, B, Skinner, N McMahon, C Pritchard, S (2011) Work, Life and VET Participation Amongst Lower-Paid Workers, National Centre for Vocational Education Research (NCVER), Adelaide.

Sawchuck, P (2003, Adult Learning and Technology in Working Class Life, Cambridge University Press, Cambridge.

Textile Clothing and Footwear Union of Australia (TCFUA) (2005) What Do I Do Next? Developing an integrated literacy strategy and model for retrenched workers in the textile, clothing and footwear industry, Australian National Training Authority, Melbourne.

Textile Clothing and Footwear Union of Australia (TCFUA) (2006) Empty Promises, TCFUA, Melbourne. 
Warren, S and Webb, S (2007) Challenging Lifelong Learning Policy Discourse: Where is structure in agency in narrative-based research?, Studies in the Education of Adults, vol 39, no 1, pp 5-21.

Watson, L (2003) Lifelong Learning in Australia, Commonwealth of Australia, Canberra.

Webb, S and Warren, S (2009) Researching Post-Compulsory Education: Beyond phenomenology?, online paper, viewed January 12 2009, $<$ http://esrea2006.ece.uth.gr/downloads/webbwarren.doc>.

Webber, M and Weller, S (2001) Refashioning the Rag Trade: Internationalising Australia's textile, clothing and footwear industries, UNSW Press, Sydney.

Weller, S (2007) Retailing, Clothing and Textiles Production in Australia, Working Paper No 29, Centre for Strategic Economic Studies, Victoria University, Melbourne.

Wojecki, A (2007) Adult Learners and the Identities They Tell: Pedagogic spaces for inviting new tales in Servage, L and Fenwick, T, eds, Learning in Community: Proceedings of the joint international conference of the Adult Education Research Conference (AERC) (48th National Conference) and the Canadian Association for the Study of Adult Education (CASAE) (26th National Conference), June 2007.

Young, M (2002) Contrasting Approaches to the Role of Qualifications in the Promotion of Lifelong Learning in Evans, K, Hodkinson, P and Unwin, L, eds, Working to Learn, Kogan Page and Stylus, London. 